OPEN ACCESS

Check for updates

\section{Changes in soft drinks purchased by British households associated with the UK soft drinks industry levy: controlled interrupted time series analysis}

\author{
David Pell, ${ }^{1}$ Oliver Mytton, ${ }^{1}$ Tarra L Penney, ${ }^{1,2}$ Adam Briggs, ${ }^{3,4}$ Steven Cummins, ${ }^{5}$ \\ Catrin Penn-Jones, ${ }^{1}$ Mike Rayner, ${ }^{3,6}$ Harry Rutter, ${ }^{7}$ Peter Scarborough, ${ }^{3,6}$ Stephen J Sharp, ${ }^{1}$ \\ Richard D Smith, ${ }^{8}$ Martin White, ${ }^{1}$ Jean Adams $^{1}$
}

For numbered affiliations see

Correspondence to: J Adams jma79@medschl.cam.ac.uk (or @jeanmadams on Twitter: ORCID 0000-0002-5733-7830) Additional material is published online only. To view please visit the journal online.

Cite this as: $B M J$ 2021;372:n254 http://dx.doi.org/10.1136/bmj.n254 end of the article.

Accepted: 15 January 2021

\begin{abstract}
OBJECTIVE

To determine changes in household purchases of drinks and confectionery one year after implementation of the UK soft drinks industry levy (SDIL).

\section{DESIGN}

Controlled interrupted time series analysis.

PARTICIPANTS

Members of a panel of households reporting their purchasing on a weekly basis to a market research company (average weekly number of participants n=22 183), March 2014 to March 2019.

\section{INTERVENTION}

A two tiered tax levied on manufacturers of soft drinks, announced in March 2016 and implemented in April 2018. Drinks with $\geq 8 \mathrm{~g}$ sugar $/ 100 \mathrm{~mL}$ (high tier) are taxed at $f 0.24 / \mathrm{L}$ and drinks with $\geq 5$ to $<8 \mathrm{~g}$ sugar $/ 100$ $\mathrm{mL}$ (low tier) are taxed at $\mathrm{f} 0.18 / \mathrm{L}$. Drinks with $<5 \mathrm{~g}$ sugar/100 mL (no levy) are not taxed.

\section{MAIN OUTCOME MEASURES}

Absolute and relative differences in the volume of, and amount of sugar in, soft drinks categories, all soft drinks combined, alcohol, and confectionery

\section{WHAT IS ALREADY KNOWN ON THIS TOPIC}

High consumption of sugar sweetened beverages (SSBs) is associated with increased risk of dental caries, obesity, type 2 diabetes, and cardiovascular disease; the World Health Organization recommends the implementation of SSB taxes to reduce consumption

The UK soft drinks industry levy (SDIL) was designed to encourage reformulation of soft drinks to remove sugar via three design features: a levy on manufacturers; inclusion of two tiers, with a higher rate charged on drinks with more sugar; and announcement of the levy two years before implementation to give manufacturers time to adjust

Although previous evaluations have explored the effect of consumer facing SSB taxes, none have explored the effect of the SDIL on purchases, taking existing trends in purchases into account

\section{WHAT THIS STUDY ADDS}

Overall one year after implementation, compared with pre-announcement trends, the total volume of all soft drinks purchased did not change but the sugar purchased in these drinks decreased by $30 \mathrm{~g}$ per household per week, or $9.8 \%-$ equivalent to three fewer teaspoons, or one $250 \mathrm{~mL}$ serving of a drink with $5 \mathrm{~g}$ sugar per $100 \mathrm{~mL}$ per person per week

No change in total volume purchased but decreases in sugar in drinks purchased means that tiered SSB taxes such as the SDIL might benefit public health without harming the soft drinks industry purchased per household per week one year after implementation of the SDIL compared with trends before the announcement of the SDIL.

\section{RESULTS}

In March 2019, compared with the counterfactual estimated from pre-announcement trends, purchased volume of drinks in the high levy tier decreased by $155 \mathrm{~mL}$ (95\% confidence interval 240.5 to $69.5 \mathrm{~mL}$ ) per household per week, equivalent to $44.3 \%$ (95\% confidence interval $59.9 \%$ to $28.7 \%$ ), and sugar purchased in these drinks decreased by $18.0 \mathrm{~g}(95 \%$ confidence interval 32.3 to $3.6 \mathrm{~g})$, or $45.9 \%(68.8 \%$ to $22.9 \%$ ). Purchases of low tier drinks decreased by $177.3 \mathrm{~mL}$ (225.3 to $129.3 \mathrm{~mL}$ ) per household per week, or $85.9 \%$ (95.1\% to $76.7 \%)$, with a $12.5 \mathrm{~g}$ (15.4 to $9.5 \mathrm{~g}$ ) reduction in sugar in these drinks, equivalent to $86.2 \%$ (94.2\% to $78.1 \%$ ). Despite no overall change in volume of no levy drinks purchased, there was an increase in sugar purchased of $15.3 \mathrm{~g}$ (12.6 to $17.9 \mathrm{~g}$ ) per household per week, equivalent to $166.4 \%$ (94.2\% to $238.5 \%)$. When all soft drinks were combined, the volume of drinks purchased did not change, but sugar decreased by $29.5 \mathrm{~g}$ (55.8 to $3.1 \mathrm{~g}$ ), or $9.8 \%(17.9 \%$ to $1.8 \%)$. Purchases of confectionery and alcoholic drinks did not change.

\section{CONCLUSIONS}

Compared with trends before the SDIL was announced, one year after implementation, the volume of soft drinks purchased did not change. The amount of sugar in those drinks was $30 \mathrm{~g}$, or $10 \%$, lower per household per week-equivalent to one $250 \mathrm{~mL}$ serving of a low tier drink per person per week. The SDIL might benefit public health without harming industry.

\section{TRIAL REGISTRATION}

ISRCTN18042742.

\section{Introduction}

High consumption of sugar sweetened beverages (SSBs) is associated with increased risk of dental caries, obesity, type 2 diabetes, and cardiovascular disease. ${ }^{1-3}$ The World Health Organization recommends the use of SSB taxes to reduce consumption. ${ }^{4} \mathrm{~A}$ systematic review of studies published to June 2018 suggests that SSB taxes lead to decreases in the sales, purchasing, and consumption of taxed drinks. ${ }^{5}$ More recent findings support this conclusion. ${ }^{6-10}$ Although price is one important mediator of these changes, ${ }^{11-16}$ other potential mechanisms include reformulation of products to reduce sugar concentration, smaller portion sizes, and increases in the perception of SSBs 
being harmful to health associated with them being grouped with other taxed products such as alcohol and tobacco. ${ }^{17}$ Furthermore, any public health benefits of reduced SSB consumption associated with SSB taxes might be negated by increased consumption of substitutes such as confectionery and alcohol. ${ }^{18-20}$

The UK soft drinks industry levy (SDIL) was one of the first taxes on SSBs explicitly designed to incentivise manufacturers of SSBs to reduce sugar content. ${ }^{2122}$ This is reflected in three design features. Firstly, the SDIL is levied on manufacturers, importers, and bottlers rather than on consumers. Secondly, the levy includes two tiers: $€ 0.24 / \mathrm{L}$ for drinks containing $\geq 8 \mathrm{~g}$ total sugar per $100 \mathrm{~mL}$, and $€ 0.18 / \mathrm{L}$ for drinks containing $\geq 5 \mathrm{~g}$ and $<8 \mathrm{~g}$ total sugar per $100 \mathrm{~mL}$. Thirdly, the SDIL was intentionally announced in 2016, two years before implementation in 2018, to allow manufacturers time to adjust. The SDIL also provides exemptions (see box 1$)^{23}$

Two before and after analyses have shown reductions of around 30\% in sales weighted sugar concentration of levy eligible drinks in the UK from before the announcement of the SDIL on 16 March 2016 to after implementation on 6 April 2018. ${ }^{24} 25$ However, background trends in purchases of sugary drinks are not stable, with decreases reported over several years. ${ }^{26}$ This makes it difficult to attribute before and after decreases in sugary drinks purchases to the SDIL. An interrupted time series analysis found that the announcement and implementation of the SDIL were together associated with a 34 percentage point reduction in the proportion of levy liable drinks with $>5$ g total sugar per $100 \mathrm{~mL}$, indicating substantial reformulation of the market. ${ }^{16}$ Changes in prices across the UK soft drink market were also reported, although it was difficult to discern clear patterns in

\section{Box 1: Glossary of terms}

Soft drinks industry levy (SDIL) - a tiered tax on manufacturers of sugar sweetened beverages

Levy exempt drinks-drinks exempt from the SDIL irrespective of sugar content; that is, drinks containing $>75 \%$ milk, drinks containing $>1.2 \%$ alcohol, and drinks sold as alcohol replacements, drinks sold as powders, $100 \%$ fruit juices, and drinks sold by manufacturers selling less than one million litres of drinks not exempt for other reasons each year

High tier drinks-drinks that are not levy exempt and contain $\geq 8 \mathrm{~g}$ of sugar per $100 \mathrm{~mL}$ Low tier drinks-drinks that are not levy exempt and contain $\geq 5 \mathrm{~g}$ to $<8 \mathrm{~g}$ of sugar per $100 \mathrm{~mL}$

No levy drinks -drinks that are not levy exempt but contain $<5 \mathrm{~g}$ of sugar per $100 \mathrm{~mL}$; we subdivided this category into drinks containing $>0 \mathrm{~g}$ to $<5 \mathrm{~g}$ of sugar per $100 \mathrm{~mL}$, drinks containing $0 \mathrm{~g}$ of sugar per $100 \mathrm{~mL}$, and bottled water

Levy liable drinks-drinks that are not levy exempt drinks; that is, the sum of high tier drinks, low tier drinks, and no levy drinks

Soft drinks-any drink not containing alcohol

Confectionery-products in the sugar confectionery and chocolate confectionery categories

Toiletries-products in the shampoo, hair conditioner, and liquid soap categories. these, with some levied categories increasing and others decreasing in price. In a controlled interrupted time series analysis including data up to the point of implementation of the SDIL, we found that the SDIL announcement was associated with changes in both the volume of, and sugar purchased in, drinks in many categories. ${ }^{27}$ However, we found no overall change in total volume of, or sugar purchased in, all soft drinks combined.

We determined whether household purchases of drinks and confectionery had changed one year after implementation of the SDIL.

\section{Methods}

Here we extend our previous analyses ${ }^{27}$ to study changes in the volume of, and amount of sugar in, household purchases of drinks in each levy tier, exempt drinks categories (including alcoholic drinks), and confectionery from two years before the announcement of the SDIL to one year after its implementation (March 2014 to March 2019). As before, we used controlled interrupted time series methods, with toiletries included as a control category. ${ }^{27}$ We compared observed changes associated with the announcement and implementation of the SDIL to the counterfactual scenarios in which the announcement and implementation did not take place. Including a full two years of data before the announcement enables us to estimate pre-intervention trends and project these forward as counterfactual scenarios. The protocol is published elsewhere ${ }^{28}$ and the study was registered. This study is reported in accordance with the strengthening the reporting of observational studies in epidemiology (STROBE) guideline (see supplementary material A).

\section{Data source}

We used data from a panel of households reporting their purchasing on a weekly basis to a market research company (Kantar Worldpanel; KWP). Participating households are asked to record all food and drink purchases brought into the home (including those ordered online and delivered) through barcodes scanners and manual report. Purchasing information is uploaded weekly, where it is linked to nutritional data collected by KWP field workers on a rolling basis. Households record their personal characteristics every four weeks and receive gift vouchers worth about $€ 100$ ( $\$ 122$; €112) annually-equivalent to $0.3 \%$ of median UK annual household income after tax in 2019 (£29600). ${ }^{29}$

KWP samples households from across Great Britain using proprietary methods. It excludes households that record fewer than six purchases weekly along with those whose adjusted weekly spend is lower than an undisclosed minimum. KWP applies weights to purchases to adjust for these exclusions and maintain the representativeness of the panel. We used these weights throughout.

The main data cleaning that occurred before analysis involved assigning products and product groups in the 
KWP dataset to SDIL relevant groups. This was done based on KWP assigned product groups, product names, and nutritional content. In previous work we found some evidence of error, but not bias, in the sugar concentration reported by KWP compared with information provided on manufacturers' websites. ${ }^{27}$

\section{Product categories: drinks, confectionery, and toiletries}

Purchased drinks that were levy liable were divided into high tier, low tier, or no levy based on sugar content (see box 1 for definitions). No levy drinks were additionally disaggregated, as described in box 1 .

As the SDIL might have led to substitution to other drinks categories, we also examined purchasing of levy exempt drinks in several categories: milk based drinks (comprising milk, milk alternatives such as soya drinks, and yoghurt based juices and drinks), alcoholic drinks (comprising both alcoholic and alcohol replacement drinks), no added sugar fruit juices, and drinks sold as powder (eg, tea, coffee, hot chocolate). Other exempt categories (infant formulas and drinks sold for medical purposes) were excluded.

We also hypothesised that the SDIL might lead to substitution from sugary drinks to other high sugar categories. To investigate this, we used sugar and chocolate confectionery purchases (referred to as confectionery).

\section{Control group}

To control for background trends in household purchases we used purchases of shampoo, hair conditioner, and liquid soap (ie, toiletries). Toiletries meet the proposed criteria for a controlled interrupted time series: they are robust to seasonality and probably have similar purchase volumes by households regardless of socioeconomic position or other potential confounders. ${ }^{30}$

\section{Outcome measures}

Most evaluations of SSB taxes focus on volume of drinks purchased. However, the SDIL's focus on reformulation makes the sugar purchased in drinks of additional public health interest. Thus, the outcome measures of interest were mean volume purchased per household per week in each of the drink categories and grams per household per week of confectionery; and mean sugar purchased per household per week from each of the drink categories and confectionery. Data were aggregated at the weekly level and analysed as a time series.

\section{Overall analysis strategy}

Previous evidence indicates that reformulation occurred after the announcement of the SDIL and price changes after implementation. ${ }^{16}$ As such, we hypothesised the SDIL might act as two linked interventions: the announcement on 16 March 2016 and implementation on 6 April 2018. ${ }^{17}$ Thus, our analysis strategy involved three separate comparisons that isolate the announcement and implementation of the SDIL and then examine the combined effect (fig 1). In the first analysis we isolated the announcement of the SDIL. Here we compared anticipatory effects on purchasing in the two years after the announcement to the counterfactual estimated from purchasing in the two years before the announcement. This replicates our previous analysis ${ }^{27}$ and is presented here for completeness. In the second analysis, we isolated the implementation of the SDIL. Here we compared purchasing in the year after implementation to the counterfactual estimated from purchasing in the two years before implementation. In the third analysis we considered both the announcement and the implementation and we compared purchasing in the year after implementation to the counterfactual estimated from purchasing in the two years before the announcement.

\section{Primary analysis: category specific analyses}

For each of the three analyses we developed separate controlled interrupted time series models for volume and sugar purchased from each levy liable and levy exempt drinks category and confectionery (fig 1). Supplementary material B provides the full model specification.

We present absolute and relative differences between observed purchasing and counterfactual scenarios in the final week of each observation period, with 95\% confidence intervals for the relative difference obtained using the multivariate delta method. ${ }^{31}$

Analysis 1: pre-post announcement (3 March 2014 - 25 March 2018; 107 pre-announcement and 106 post-announcement)

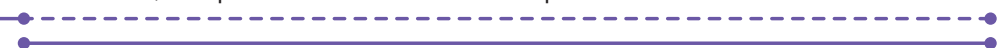

Analysis 2: pre-post implementation (21 March 2016 - 24 March 2019; 106 pre-implementation and 51 post-implementation)

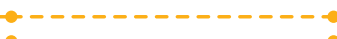

Analysis 3: pre-post announcement and implementation (3 March 2014 - 24 March 2019; 107 pre-announcement and 51 post-implementation) Analysis 3. pre-post announcement and implementation 51 post-implementation 
Secondary analysis: all soft drinks categories combined, irrespective of levy eligibility

Levy exempt drinks include drinks that might contain comparable amounts of sugar to levy liable products. To examine the extent to which the SDIL impacted on the purchased volume of, and amount of sugar in, soft drinks, regardless of SDIL liability, we carried out controlled interrupted time series analysis, combining purchases of all soft drinks (irrespective of sugar content; ie, high tier, low tier, no levy, milk and milk based drinks, no added sugar fruit juice, and drinks sold as powders), levy liable drinks (irrespective of sugar content; ie, high tier, low tier, and no levy drinks), and according to sugar content based on levy tiers (irrespective of levy eligibility; ie, all soft drinks with $\geq 8$ g of sugar per $100 \mathrm{~mL}$, all soft drinks with $\geq 5 \mathrm{~g}$ to $<8 \mathrm{~g}$ of sugar per $100 \mathrm{~mL}$, and all soft drinks with $<5 \mathrm{~g}$ of sugar per $100 \mathrm{~mL}$ ).

\section{Sensitivity analyses}

Excluding small manufacturers-the SDIL exempts drinks from manufacturers and producers who sell less than one million litres of levy liable drinks annually. As we were unable to obtain a list of exempt manufacturers, our main analyses include all manufacturers. We conducted sensitivity analyses to examine the effect of excluding manufacturers who we estimated to be small. The total purchase volume was summed by manufacturer by year across the five years in the KWP dataset, and a mean purchase volume per year for each manufacturer was calculated. In the first sensitivity analysis, we excluded manufacturers with a mean of less than one million litres purchased per year. Acknowledging KWP data excludes purchases not brought home, we repeated these analyses excluding manufacturers with mean annual purchased volumes of $<0.5$ million litres in KWP. We were unable to access accurate estimates of the proportion of all drinks purchases brought home. This value reflects an arbitrary, but we think conservative, estimate of the minimum proportion of drinks brought home.

Interrupted time series without a control categoryToiletries were chosen as a control condition a priori to account for background trends in household purchases. It is, however, possible that a more appropriate control exists. As we only have access to data on purchasing of the categories described here (confectionery, drinks, toiletries), we were not able to examine alternative potential control categories. To examine the effect of the decision to use toiletries as the control category, we performed an additional sensitivity analysis with no control condition.

\section{Changes to protocol}

We made several changes to the published protocol. ${ }^{28}$ KWP provided additional data that allowed us to increase the precision of our estimates. Specifically, we were able to increase the pre-announcement study period from 104 to 107 weeks and reduce the unit of analysis from purchases every four weeks to purchases every week. We originally intended to include purchases not brought home. We excluded these purchases, however, as these data were not available before mid-2015, meaning that robust pre-announcement trends could not be estimated. Although we originally intended to combine all no levy drinks, we present these disaggregated into those with $>0 \mathrm{~g}$ and $<5 \mathrm{~g}$ of sugar per $100 \mathrm{~mL}, 0 \mathrm{~g}$ of sugar per $100 \mathrm{~mL}$, and bottled water, as trends for these different categories are noticeably different. Our original intention to explore potential disparities across socioeconomic groups will be pursued in future work.

\section{Patient and public involvement}

The steering group for the wider SDIL evaluation includes two lay members and meets twice a year. Patients and the public were not involved in developing the research question, the outcome measures, the design, or the conduct of the work reported here. The steering group has regularly contributed ideas for routes to dissemination.

\section{Results}

About 31 million purchases of drinks, confectionery, and toiletries from March 2014 to March 2019 were included from a mean of 22183 households each week. The characteristics of included households remained consistent over the study period, and after weighting they largely reflected households in 201419 in the UK (see supplementary table 1).

Table 1 summarises the households' weekly purchased volumes of, and amounts of sugar in, drinks and other categories over the study period. Substantial reductions in volume of, and sugar in, purchases of SDIL liable drinks were observed in the high and low tiers over time. These reductions were accompanied by a smaller increase in volume of no levy drinks purchased, but proportionally much greater increases in sugar purchased in these drinks.

\section{Primary analysis: category specific results}

Results of the controlled interrupted time series analyses of purchased volume of, and sugar in, levy liable drinks and confectionery are shown in figure 2 (volume) and figure 3 (sugar). Absolute and relative changes are summarised in table 2 and table 3 . Supplementary tables $2 \mathrm{a}$ and b show level and trend changes from these models. Supplementary figures $1 \mathrm{a}$ and $b$ show similar figures and data for subcategories of no levy drinks and exempt categories.

\section{High tier drinks}

The trend in purchased volume of, and sugar in, high tier drinks continued downwards throughout the study period. The implementation, but not announcement, of the SDIL was associated with a reduction in purchased volume of, and sugar in, these drinks. The volume of high tier drinks purchased was $139.0 \mathrm{~mL}$ (95\% confidence interval 191.0 to $86.9 \mathrm{~mL}$ ) per household per week, or $41.6 \%$ (95\% confidence interval $53.7 \%$ to $29.5 \%$ ), lower in March 2019 compared with the counterfactual estimated from pre-implementation 


\begin{tabular}{|c|c|c|c|c|c|c|}
\hline & \multicolumn{3}{|c|}{ Mean (SD) volume ( $\mathrm{mL}$ ) per household weekly } & \multicolumn{3}{|c|}{ Mean (SD) amount of sugar (g) per household weekly } \\
\hline & $\begin{array}{l}\text { Pre-announcement: } \\
\text { Mar 2014-Mar } 2016\end{array}$ & $\begin{array}{l}\text { Post-announcement: } \\
\text { Mar 2016-Mar } 2018\end{array}$ & $\begin{array}{l}\text { Post-implementation: } \\
\text { Apr 2018-Mar } 2019\end{array}$ & $\begin{array}{l}\text { Pre-announcement: } \\
\text { Mar 2014-Mar } 2016\end{array}$ & $\begin{array}{l}\text { Post-announcement: } \\
\text { Mar 2016-Mar } 2018\end{array}$ & $\begin{array}{l}\text { Post-implementation: } \\
\text { Apr 2018-Mar } 2019\end{array}$ \\
\hline \multicolumn{7}{|c|}{ Levy liable drinks (sugar/100 mL) } \\
\hline High tier ( $\geq 8 \mathrm{~g}$ ) & $951(150)$ & $677(159)$ & $297(70)$ & $105.6(16.5)$ & $75.2(17.3)$ & $32.7(7.9)$ \\
\hline Low tier $(\geq 5 \mathrm{~g}$ to $<8 \mathrm{~g}$ & $168(40)$ & $144(43)$ & $65(28)$ & $10.9(2.7)$ & $9.5(2.8)$ & $4.4(1.9)$ \\
\hline No levy ( $<5 \mathrm{~g})$ : & $2517(235)$ & $2576(298)$ & $2935(400)$ & $12.5(1.7)$ & $12.4(2.6)$ & $21.5(4.8)$ \\
\hline$>0 \mathrm{~g}$ to $<5 \mathrm{~g}$ & $835(87)$ & $764(99)$ & $858(133)$ & $12.5(1.7)$ & $12.4(2.6)$ & $21.5(4.8)$ \\
\hline $0 \mathrm{~g}$ & $1073(116)$ & $1097(148)$ & $1346(200)$ & $0(0)$ & $0(0)$ & $0(0)$ \\
\hline Bottled water & $609(78)$ & $714(90)$ & $730(124)$ & $0(0)$ & $0(0)$ & $0(0)$ \\
\hline \multicolumn{7}{|l|}{ Levy exempt drinks } \\
\hline Alcoholic drinks & $1959(452)$ & $1871(516)$ & $1806(524)$ & . & . & . \\
\hline $\begin{array}{l}\text { Milk and milk based } \\
\text { drinks: }\end{array}$ & $3705(203)$ & $3460(224)$ & $3358(241)$ & $180.3(9.9)$ & $167.9(11.1)$ & $160.9(11.3)$ \\
\hline Milk & $3573(194)$ & $3338(216)$ & $3237(234)$ & $167.5(9.0)$ & $156.5(10.2)$ & $150.3(10.7)$ \\
\hline Milk based drinks & $132(14)$ & $122(16)$ & $121(11)$ & $12.8(1.4)$ & $11.4(1.6)$ & $10.6(1.0)$ \\
\hline $\begin{array}{l}\text { Fruit juices with no } \\
\text { added sugar }\end{array}$ & $534(37)$ & $493(51)$ & $497(57)$ & $52.7(3.8)$ & $47.8(5.0)$ & $47.4(5.5)$ \\
\hline $\begin{array}{l}\text { Drinks sold as } \\
\text { powders }(\mathrm{g})\end{array}$ & $100(13)$ & $87(11)$ & $82(12)$ & $21.6(3.4)$ & $18.3(3.2)$ & $16.5(3.0)$ \\
\hline Confectionery (g) & $325(98)$ & $301(95)$ & $287(93)$ & $182.5(55.0)$ & $169.0(53.3)$ & $161.0(52.1)$ \\
\hline Toiletries & $125(10)$ & $119(10)$ & $118(11)$ & . & . & . \\
\hline
\end{tabular}

trends. Sugar purchased in these drinks decreased by $16.1 \mathrm{~g}$ (95\% confidence interval 24.8 to $7.3 \mathrm{~g}$ ) per household per week, or $43.1 \%$ (61.1\% to $25.1 \%)$. Results compared with the counterfactual estimated from pre-announcement trends were similar.

\section{Low tier drinks}

Purchased volume of, and sugar in, low tier drinks gradually increased before the announcement of the SDIL. The announcement was associated with a reversal of this trend, but implementation was not associated with any additional statistically significant change. Compared with the counterfactual estimated from pre-announcement trends, in March 2019 the volume of purchased low tier drinks per household per week decreased by $177.3 \mathrm{~mL}$ (225.3 to $129.3 \mathrm{~mL}$ ), or $85.9 \%$ (95.1\% to $76.7 \%$ ); and sugar purchased in these drinks decreased by $12.5 \mathrm{~g}$ (15.4 to $9.5 \mathrm{~g}$ ) per household per week, or $86.2 \%$ (94.2\% to $78.1 \%$ ).

\section{No levy drinks}

Before the announcement of the SDIL there was a gradual upward trend in volume of purchased no levy drinks but a gradual downward trend in purchased sugar. Announcement of the SDIL was associated with a non-significant decrease in volume of no levy drinks purchased, whereas implementation was associated with a statistically significant increase in no levy drinks purchased. Overall, purchased volume of no levy drinks in March 2019 was $210.5 \mathrm{~mL}(-100.1$ to $521.2 \mathrm{~mL}$ ), equivalent to $7.7 \%$ ( $-4.4 \%$ to $19.9 \%$ ) higher compared with the counterfactual of preannouncement trends, although this did not reach statistical significance.

Increases were, however, found in sugar purchased from no levy drinks associated with the announcement, but not the implementation, of the SDIL. Compared with the counterfactual of pre-announcement trends, in March 2019 sugar purchased in no levy drinks increased by $15.3 \mathrm{~g}$ (12.6 to $17.9 \mathrm{~g}$ ) per household per week, or $166.4 \%$ (94.2\% to $238.5 \%$ ).

Changes in purchased volume of subcategories within the no levy drinks group were not uniform. Both the announcement and the implementation of the SDIL were associated with significant decreases in bottled water purchased. In contrast, the implementation, but not announcement, of the SDIL was associated with increases in purchased drinks with no sugar and with $>0$ to $<5 \mathrm{~g}$ total sugar per $100 \mathrm{~mL}$.

\section{Levy exempt drinks and confectionery}

Overall, the announcement and implementation of the SDIL were associated with no statistically significant changes in purchased volume of levy exempt drinks or confectionery. An overall reduction was, however, found in sugar purchased from milk and milk based drinks. Compared with the counterfactual of preannouncement trends, in March 2019 sugar purchased in these drinks decreased by $11.9 \mathrm{~g}$ (23.1 to $0.8 \mathrm{~g}$ ) per household per week, equivalent to $7.4 \%(13.8 \%$ to $0.9 \%)$.

\section{Secondary analysis: all soft drinks categories combined}

Supplementary table 3a and supplementary figure 2 summarise the results of the controlled interrupted time series analyses of the associated effects of the SDIL on purchased volume of, and sugar from, all soft drinks categories combined, irrespective of levy eligibility. Supplementary table 3b summarises absolute and relative changes in volume of, and sugar in, all soft drinks and confectionery purchased.

Overall, compared with the counterfactual estimated from pre-announcement trends, no change was 


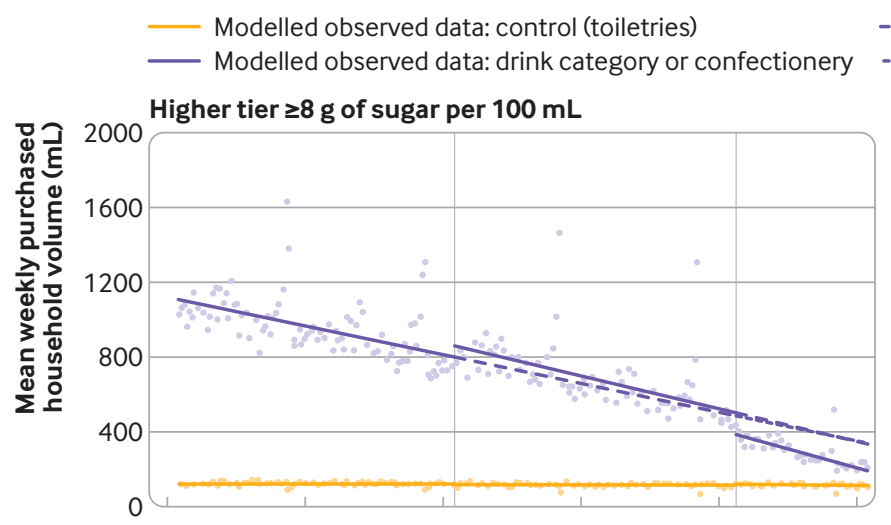

$$
\text { ----- Pre-implementaion counterfactual }
$$
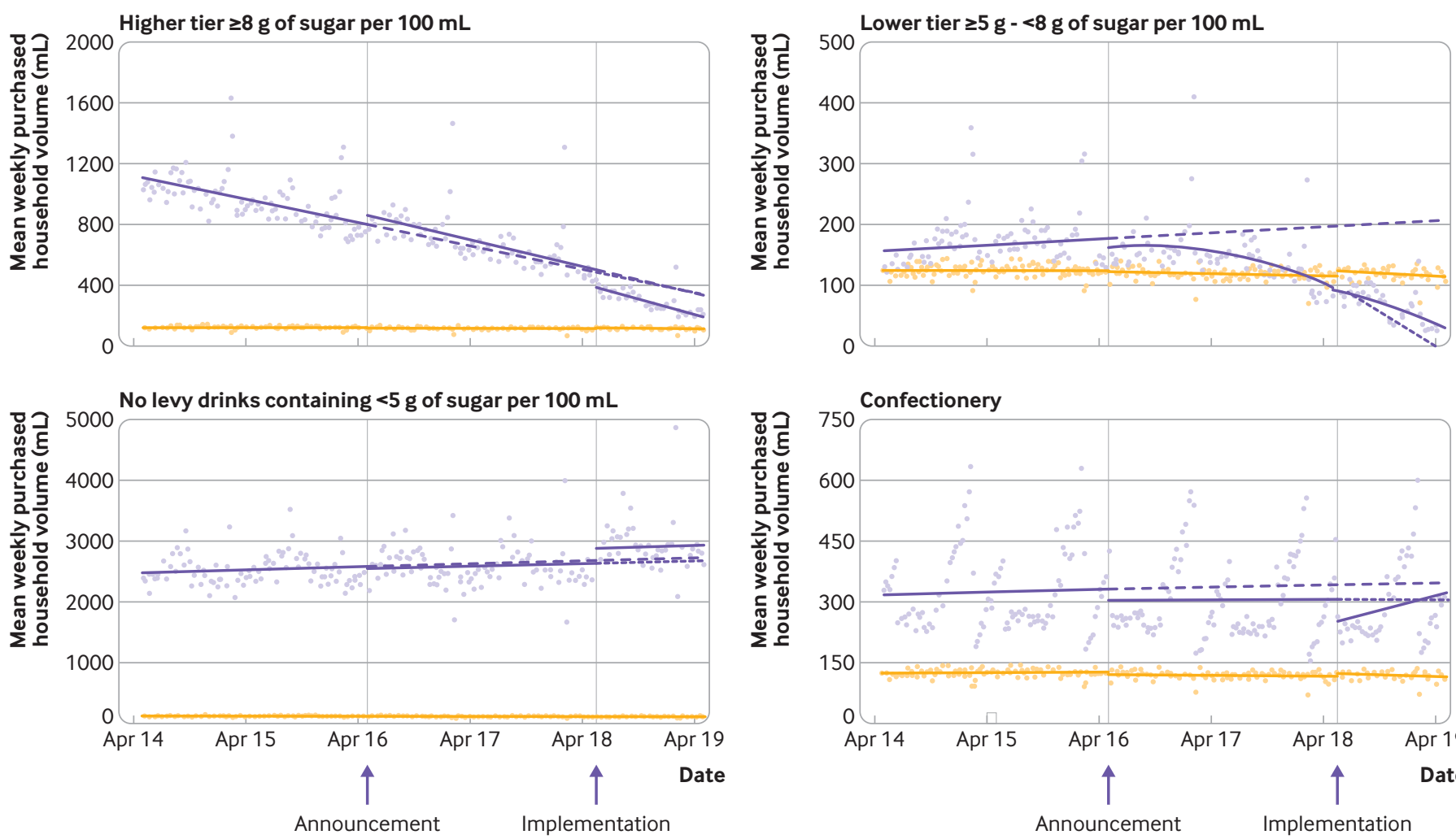

Fig 2 | Observed and modelled volume of drinks liable to the Soft Drinks Industry Levy (SDIL), and weight of confectionery purchased by each household weekly, March 2014 to March 2019. Points are observed data; coloured lines are modelled data; the first vertical line indicates the announcement of the SDIL; the second vertical line indicates the implementation of the SDIL; the Y axis varies in scale between panels to maximise the resolution of figures; modelled purchases are presented as smoothed lines, including averaged effects for seasonality and the impact of Christmas and January, and, for confectionery, Easter

observed in volume of all soft drinks purchased in March 2019. A reduction was, however, found in sugar purchased in all soft drinks (including exempt drinks) combined of $29.5 \mathrm{~g}$ per household per week (55.8 to $3.1 \mathrm{~g})$, equivalent to $9.8 \%$ (17.9\% to $1.8 \%)$.

\section{Sensitivity analyses}

Excluding manufacturers of levy liable products with less than one million and less than 500000 litres of purchased drinks annually in our dataset was associated with small changes in the magnitude of estimated coefficients, but with no change in the direction or statistical significance of any findings (supplementary tables $4 \mathrm{a}$ to $\mathrm{b}$ ).

Removing the control category led to wider confidence intervals in a small number of cases such that absolute and relative changes in volume were not statistically different from the pre-implementation counterfactuals (see supplementary material G).

\section{Discussion}

Taking account of pre-existing trends, this study found that one year after implementation of the SDIL, sugar purchased from soft drinks that were taken home decreased by $30 \mathrm{~g}$ per household per week. No evidence was found of a statistically significant change in purchased volume. Assuming a mean UK household size of 2.4 people, $^{32}$ this is equivalent to a reduction in sugar consumption from SSBs of $12.5 \mathrm{~g}$ per person per week, or equivalent to the replacement of one $250 \mathrm{~mL}$ serving of a drink with $5 \mathrm{~g}$ sugar per $100 \mathrm{~mL}$ per person per week with a sugar-free alternative. A modelling study conducted before implementation of the SDIL found that if the levy achieved reformulation it could be expected to lead to a decrease in sugar consumption from SSBs of 7-38 g per person per week and that this would be associated with a reduction in the number of obese individuals in the UK of 0.2-0.9\% and a reduction in incidence cases of type 2 diabetes of 0.8-4.4 per 1000 person years. The reduction in sugar from SSBs we report one year after implementation of the SDIL is within this range.

\section{Strengths and weaknesses of this study}

In this study we used a large, nationally representative dataset, included a control category, and explored changes in two potential substitute categories (alcohol and confectionery).

We only included purchases brought into homes. Although KWP also collects data on other purchases, this smaller panel was established in mid-2015 and so was unsuitable for our analyses because robust 


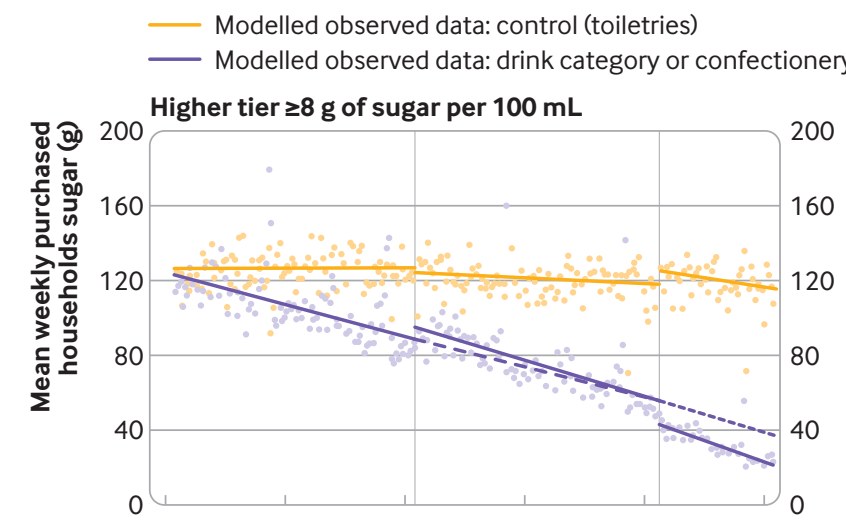

$$
\text { ----- Pre-implementaion counterfactual }
$$
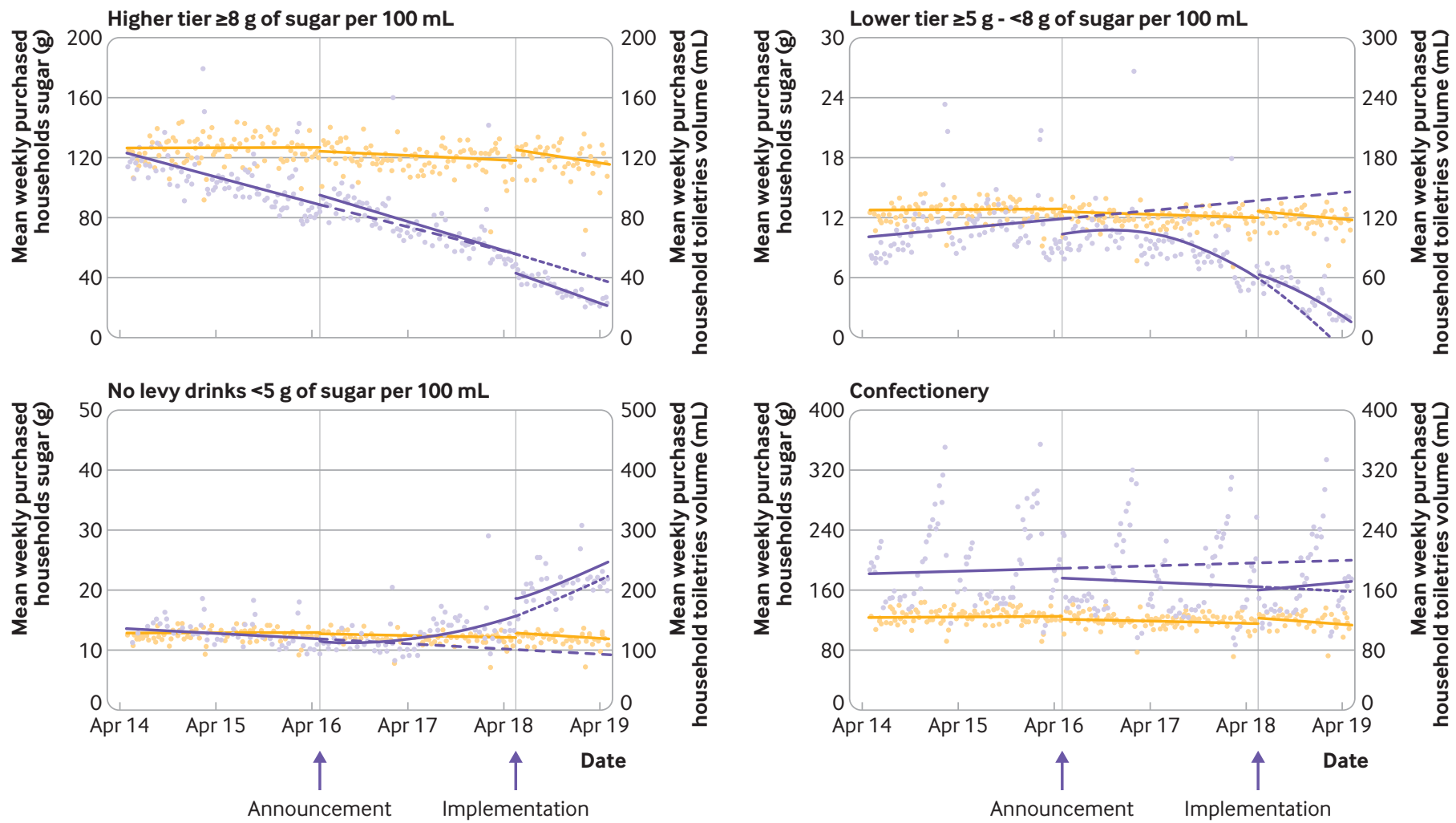

Fig 3 | Observed and modelled amount of sugar in drinks liable to the Soft Drinks Industry Levy and confectionery purchased by each household weekly, March 2014 to March 2019. Points are observed data; coloured lines are modelled data; the first vertical line indicates the announcement of the SDIL; the second vertical line indicates the implementation of the SDIL; the Y axis varies in scale between panels to maximise the resolution of figures; modelled purchases are presented as smoothed lines, including averaged effects for seasonality and the impact of Christmas and January, and, for confectionery, Easter

pre-announcement trends could not be estimated. KWP data are collected at the household level and do not take account of waste or differential sharing within households. Nevertheless, the data provide a reasonable estimate of consumption. ${ }^{33}$ We did not assess changes in other categories beyond soft drinks, alcohol, and confectionery.

The estimate of effect size in interrupted time series analyses is based on a modelled counterfactual that might be inaccurate. For example, the strong downward trend in higher tier drinks before the announcement of the SDIL might not have continued. Attribution of effects in interrupted time series analyses is vulnerable to co-interventions. The SDIL is part of a wider sugar reduction strategy, although this has been found to have achieved minimal changes beyond those attributable to the SDIL. ${ }^{24}$

The personal characteristics of the panel remained similar over the study period, and proprietary weightings were used to account for non-consumers and to adjust for variations in panel composition. Households participating in KWP are slightly more likely to be from lower social position and to have no qualifications compared with UK households generally. This might reflect the relative value placed on the small rewards for participation by different households and could limit the generalisability of our findings. If households from lower socioeconomic backgrounds are more likely to change purchasing as a result of the SDIL, then we could have marginally overestimated the effect of the SDIL. However, while we previously found that the price of soft drinks in the UK did change after implementation of the SDIL, no clear pattern was found, with the price of some groups of drinks increasing and others decreasing. ${ }^{16}$ We previously found no systematic differences between the sugar content of drinks reported in KWP data and contemporaneous values listed on supermarket websites. $^{27}$

\section{Comparison with other work}

Our finding that the SDIL was associated with a reduction in purchased sugar from all soft drinks is consistent with previous analyses that focused on the SDIL. ${ }^{24}{ }^{25}$ Although our estimate of the reduction in sugar consumption from all soft drinks associated with the levy (9.8\%) was less than that estimated by others (29\%), this previous work did not take account of preexisting trends. ${ }^{24}$

We found that the reduction in purchased sugar from all soft drinks occurred despite no change in volume of all soft drinks purchased. This is 


\begin{tabular}{|c|c|c|c|c|c|c|}
\hline & \multicolumn{2}{|c|}{$\begin{array}{l}\text { Analysis 1: pre-post announcement } \\
\text { (Mar 2014-Mar 2018) }\end{array}$} & \multicolumn{2}{|c|}{$\begin{array}{l}\text { Analysis 2: pre-post implementation } \\
\text { (Mar 2016-Mar 2019) }\end{array}$} & \multicolumn{2}{|c|}{$\begin{array}{l}\text { Analysis 3: pre-post announcement and } \\
\text { implementation (Mar 2014-Mar 2019) }\end{array}$} \\
\hline & $\begin{array}{l}\text { Absolute } \\
\text { change (mL or } g \text { ) }\end{array}$ & $\begin{array}{l}\text { Relative } \\
\text { change (\%) }\end{array}$ & $\begin{array}{l}\text { Absolute } \\
\text { change ( } \mathrm{mL} \text { or } \mathrm{g})\end{array}$ & $\begin{array}{l}\text { Relative } \\
\text { change (\%) }\end{array}$ & $\begin{array}{l}\text { Absolute } \\
\text { change (mL or } g)\end{array}$ & $\begin{array}{l}\text { Relative } \\
\text { change (\%) }\end{array}$ \\
\hline \multicolumn{7}{|c|}{ Levy liable drinks (sugar/100 mL) } \\
\hline High tier ( $\geq 8 \mathrm{~g}$ ) & $\begin{array}{l}7.1 \\
(-57.5 \text { to } 71.7)\end{array}$ & $\begin{array}{l}1.4 \\
(-11.7 \text { to } 14.6)\end{array}$ & $\begin{array}{l}-139.0 \\
(-191.0 \text { to }-86.9)^{\star}\end{array}$ & $\begin{array}{l}-41.6 \\
(-53.7 \text { to }-29.5)^{\star}\end{array}$ & $\begin{array}{l}-155.0 \\
(-240.5 \text { to }-69.5)^{\star}\end{array}$ & $\begin{array}{l}-44.3 \\
(-59.9 \text { to }-28.7)^{\star}\end{array}$ \\
\hline Low tier $(\geq 5 \mathrm{~g}$ to $<8 \mathrm{~g})$ * & $\begin{array}{l}-104.2 \\
(-143.2 \text { to }-65.1)\end{array}$ & $\begin{array}{l}-52.6 \\
(-65.1 \text { to }-40.2)^{\star}\end{array}$ & $\begin{array}{l}22.7 \\
(-46.0 \text { to } 91.4)\end{array}$ & $\begin{array}{l}352.0 \\
(-4312.8 \text { to } 5016.7)\end{array}$ & $\begin{array}{l}-177.3 \\
(-225.3 \text { to }-129.3)^{\star}\end{array}$ & $\begin{array}{l}-85.9 \\
(-95.1 \text { to }-76.7)^{*}\end{array}$ \\
\hline No levy ( $<5 \mathrm{~g})$ : & $\begin{array}{l}-42.1 \\
(-280.6 \text { to } 196.3)^{\star}\end{array}$ & $\begin{array}{l}-1.6 \\
(-10.4 \text { to } 7.2)\end{array}$ & $\begin{array}{l}261.0 \\
(69.1 \text { to } 452.9)^{\star}\end{array}$ & $\begin{array}{l}9.8 \\
(2.1 \text { to } 17.4)^{\star}\end{array}$ & $\begin{array}{l}210.5 \\
(-100.1 \text { to } 521.2)\end{array}$ & $\begin{array}{l}7.7 \\
(-4.4 \text { to } 19.9) \\
\end{array}$ \\
\hline$>0 \mathrm{~g}$ to $<5 \mathrm{~g}$ & $\begin{array}{l}26.2 \\
(-51 \text { to } 103.3) \\
\end{array}$ & $\begin{array}{l}3.6 \\
(-7.4 \text { to } 14.6) \\
\end{array}$ & $\begin{array}{l}170.7 \\
(108.6 \text { to } 232.9)^{\star}\end{array}$ & $\begin{array}{l}23.2 \\
(13.5 \text { to } 32.9)^{\star}\end{array}$ & $\begin{array}{l}217.4 \\
(116.5 \text { to } 318.4)^{\star}\end{array}$ & $\begin{array}{l}31.5 \\
(12.8 \text { to } 50.2)^{\star}\end{array}$ \\
\hline $0 \mathrm{~g}$ & $\begin{array}{l}11.3 \\
(-113.9 \text { to } 136.5)\end{array}$ & $\begin{array}{l}1.0 \\
(-10.2 \text { to } 12.2)\end{array}$ & $\begin{array}{l}174.1 \\
(73.6 \text { to } 274.5)^{\star}\end{array}$ & $\begin{array}{l}14.9 \\
(5.5 \text { to } 24.3)^{\star}\end{array}$ & $\begin{array}{l}197.0 \\
(36.7 \text { to } 357.4)^{\star}\end{array}$ & $\begin{array}{l}17.2 \\
(1.1 \text { to } 33.3)^{*}\end{array}$ \\
\hline Bottled water & $\begin{array}{l}-81.9 \\
(-129.9 \text { to }-33.8)^{\star}\end{array}$ & $\begin{array}{l}-9.8 \\
(-15.0 \text { to }-4.6)^{*}\end{array}$ & $\begin{array}{l}-101.2 \\
(-143.5 \text { to }-58.8)^{\star}\end{array}$ & $\begin{array}{l}-12.8 \\
\left(-17.8 \text { to }-7.7^{*}\right.\end{array}$ & $\begin{array}{l}-216.4 \\
(-285.5 \text { to }-147.4)^{\star}\end{array}$ & $\begin{array}{l}-23.8 \\
(-30.0 \text { to }-17.6)^{\star}\end{array}$ \\
\hline \multicolumn{7}{|l|}{ Levy exempt drinks } \\
\hline Alcoholic drinks & $\begin{array}{l}-91.2 \\
(-355.1 \text { to } 172.7)\end{array}$ & $\begin{array}{l}-4.8 \\
(-18 \text { to } 8.5)\end{array}$ & $\begin{array}{l}-83.5 \\
(-296.2 \text { to } 129.1)\end{array}$ & $\begin{array}{l}-4.7 \\
(-16.4 \text { to } 7)\end{array}$ & $\begin{array}{l}-205.5 \\
(-554.7 \text { to } 143.7)\end{array}$ & $\begin{array}{l}-10.9 \\
(-27.6 \text { to } 5.9)\end{array}$ \\
\hline Milk and milk based drinks & $\begin{array}{l}-226.5 \\
(-362.6 \text { to }-90.4)^{\star}\end{array}$ & $\begin{array}{l}-7.0 \\
(-10.9 \text { to }-3.0)^{\star}\end{array}$ & $\begin{array}{l}168.7 \\
(61.8 \text { to } 275.6)^{\star}\end{array}$ & $\begin{array}{l}5.9 \\
(2.0 \text { to } 9.7)^{\star}\end{array}$ & $\begin{array}{l}-152.8 \\
(-325.7 \text { to } 20.1)\end{array}$ & $\begin{array}{l}-4.8 \\
(-9.9 \text { to } 0.4)\end{array}$ \\
\hline No added sugar fruit juices & $\begin{array}{l}-9.7 \\
(-48.1 \text { to } 28.7)\end{array}$ & $\begin{array}{l}-2.0 \\
(-9.6 \text { to } 5.7)\end{array}$ & $\begin{array}{l}-1.6 \\
(-32.5 \text { to } 29.3)\end{array}$ & $\begin{array}{l}-0.3 \\
(-6.8 \text { to } 6.1)\end{array}$ & $\begin{array}{l}-7.2 \\
(-57.3 \text { to } 43) \\
\end{array}$ & $\begin{array}{l}-1.5 \\
(-11.7 \text { to } 8.8)\end{array}$ \\
\hline Drinks sold as powders (g) & $\begin{array}{l}-16.3 \\
(-29.8 \text { to }-2.8)^{\star}\end{array}$ & $\begin{array}{l}-17.2 \\
(-29.4 \text { to }-5.1)^{\star}\end{array}$ & $\begin{array}{l}13.5 \\
(2.7 \text { to } 24.3)^{\star}\end{array}$ & $\begin{array}{l}19.2 \\
(1.9 \text { to } 36.5)^{*}\end{array}$ & $\begin{array}{l}-9.2 \\
(-26.7 \text { to } 8.4)\end{array}$ & $\begin{array}{l}-9.9 \\
(-27.1 \text { to } 7.4)\end{array}$ \\
\hline Confectionery (g) & $\begin{array}{l}-36.4 \\
(-186.5 \text { to } 113.6)\end{array}$ & $\begin{array}{l}-10.7 \\
(-51 \text { to } 29.5)\end{array}$ & $\begin{array}{l}16.5 \\
(-104.8 \text { to } 137.7)\end{array}$ & $\begin{array}{l}5.5 \\
(-35.9 \text { to } 46.8)\end{array}$ & $\begin{array}{l}-25.7 \\
(-213.4 \text { to } 161.9)\end{array}$ & $\begin{array}{l}-7.5 \\
(-58.3 \text { to } 43.3)\end{array}$ \\
\hline
\end{tabular}

The counterfactual for low tier drinks crossed $0 \mathrm{~mL}$ shortly before the end of the study period thus predicting negative purchases; therefore the non-counterfactual estimate at the end of the study period was compared with the final week during which the counterfactual was a positive number.

*Significant difference at $95 \%$ confidence interval level.

consistent with previously reported reductions in the sugar concentration of drinks associated with the SDIL. ${ }^{16}$ The estimated effect size is also within the range of reformulation scenarios modelled before implementation (ie, a reduction of 17 to $90 \mathrm{~g}$ of sugar per household per week). ${ }^{34}$

Evaluations of other SSB taxes have revealed a consistent trend of reductions in purchasing of taxed drinks and no change in purchasing of untaxed drinks. ${ }^{5}$ We found similar, with both volume of, and sugar in, high and low tier drinks decreasing overall. These reductions in volume of taxed drinks were offset by increases in volume of other drinks purchased. Despite some increases in sugar purchased in some categories of untaxed drinks, these did not offset decreases in sugar purchased from taxed drinks.

\section{Meaning of the study and implications for policymakers}

Our main findings are that the SDIL was associated with a reduction in purchased sugar from all soft drinks with no evidence of a commensurate reduction in the volume of soft drinks purchased. Given the reformulation associated with the SDIL already documented, ${ }^{16}$ it is probable that the changes we report were driven by reductions in the sugar concentration of available drinks, alongside consumers switching to lower sugar alternatives. Despite the overall reduction we found in sugar purchased in soft drinks, the average amount of sugar purchased in drinks that are not subject to the levy paradoxically increased after implementation of the SDIL, with many drinks that previously had sugar concentrations above the levy threshold now having them just below the threshold. This seems to reflect manufacturers reformulating to target thresholds. Lowering the threshold sugar concentration at which drinks become eligible for the SDIL could potentially lead to greater overall reductions in sugar concentrations and sugar purchased in soft drinks, as could extension of the SDIL to milk based drinks and other currently exempt categories that sometimes contain high levels of sugar.

Nevertheless, the overall reduction in sugar with no change in volume we report here might represent a valuable benefit for public health with little harm to the food industry. The SDIL has also been found to have had no long term negative effects on the share value or turnover of UK soft drinks companies, ${ }^{35} 36$ suggesting that, contrary to industry predictions, public health can gain without negatively affecting the soft drinks sector.

We note a marked pre-implementation decline in purchasing of high levy tier drinks. It is possible that this was, at least in part, driven by concern from industry about a possible SSB tax, leading to some pre-announcement reformulation; alongside growing consumer awareness of, and concerns about, the health impacts of SSBs. ${ }^{37}$ Although it is uncertain if this trend would have continued in the absence of the SDIL, it is likely to be beneficial for health.

Reassuringly, we did not observe any change in purchasing of potentially harmful substitutes (ie, alcohol and confectionery) associated with the SDIL, which could have partially or wholly offset any public 


\begin{tabular}{|c|c|c|c|c|c|c|}
\hline & \multicolumn{2}{|c|}{$\begin{array}{l}\text { Analysis 1: pre-post announcement } \\
\text { (Mar 2014-Mar 2018) }\end{array}$} & \multicolumn{2}{|c|}{$\begin{array}{l}\text { Analysis 2: pre-post implementation } \\
\text { (Mar 2016-Mar 2019) }\end{array}$} & \multicolumn{2}{|c|}{$\begin{array}{l}\text { Analysis 3: pre-post announcement and } \\
\text { implementation (Mar 2014-Mar 2019) }\end{array}$} \\
\hline & $\begin{array}{l}\text { Absolute } \\
\text { change (g) }\end{array}$ & $\begin{array}{l}\text { Relative } \\
\text { change (\%) }\end{array}$ & $\begin{array}{l}\text { Absolute } \\
\text { change (g) }\end{array}$ & $\begin{array}{l}\text { Relative } \\
\text { change (\%) }\end{array}$ & $\begin{array}{l}\text { Absolute } \\
\text { change (g) }\end{array}$ & $\begin{array}{l}\text { Relative } \\
\text { change (\%) }\end{array}$ \\
\hline \multicolumn{7}{|c|}{ Levy liable drinks (sugar/100 mL) } \\
\hline High tier ( $\geq 8 \mathrm{~g}$ ) & $\begin{array}{l}0.6 \\
(-10.2 \text { to } 11.4)\end{array}$ & $\begin{array}{l}1.1 \\
(-18.7 \text { to } 20.8)\end{array}$ & $\begin{array}{l}-16.1 \\
(-24.8 \text { to }-7.3)^{\star}\end{array}$ & $\begin{array}{l}-43.1 \\
(-61.1 \text { to }-25.1)^{\star}\end{array}$ & $\begin{array}{l}-18.0 \\
(-32.3 \text { to }-3.6)^{\star}\end{array}$ & $\begin{array}{l}-45.9 \\
(-68.8 \text { to }-22.9)^{*}\end{array}$ \\
\hline Low tier $(\geq 5 \mathrm{~g}$ to $<8 \mathrm{~g})$ & $\begin{array}{l}-7.5 \\
(-9.8 \text { to }-5.2)^{\star}\end{array}$ & $\begin{array}{l}-54.5 \\
(-65.1 \text { to }-43.9)^{\star}\end{array}$ & $\begin{array}{l}0.9 \\
(-3.1 \text { to } 5.0)\end{array}$ & $\begin{array}{l}84.4 \\
(-554.9 \text { to } 723.6)\end{array}$ & $\begin{array}{l}-12.5 \\
(-15.4 \text { to }-9.5)^{\star}\end{array}$ & $\begin{array}{l}-86.2 \\
(-94.2 \text { to }-78.1)^{\star}\end{array}$ \\
\hline No levy $(<5 \mathrm{~g}) \dagger$ & $\begin{array}{l}5.7 \\
(3.6 \text { to } 7.8)^{\star}\end{array}$ & $\begin{array}{l}56.9 \\
(25.9 \text { to } 87.8)^{\star}\end{array}$ & $\begin{array}{l}2.2 \\
(-2.2 \text { to } 6.6)\end{array}$ & $\begin{array}{l}9.9 \\
(-11.6 \text { to } 31.4)\end{array}$ & $\begin{array}{l}15.3 \\
(12.6 \text { to } 17.9)^{\star}\end{array}$ & $\begin{array}{l}166.4 \\
(94.2 \text { to } 238.5)^{\star}\end{array}$ \\
\hline $\begin{array}{l}>0 \mathrm{~g} \text { to }<5 \mathrm{~g} \text { sugar } \\
\text { per } 100 \mathrm{~mL} t\end{array}$ & $\begin{array}{l}5.7 \\
(3.6 \text { to } 7.8)^{\star}\end{array}$ & $\begin{array}{l}56.9 \\
(25.9 \text { to } 87.8)^{\star}\end{array}$ & $\begin{array}{l}2.2 \\
(-2.2 \text { to } 6.6)\end{array}$ & $\begin{array}{l}9.9 \\
(-11.6 \text { to } 31.4)\end{array}$ & $\begin{array}{l}15.3 \\
(12.6 \text { to } 17.9)^{\star}\end{array}$ & $\begin{array}{l}166.4 \\
(94.2 \text { to } 238.5)^{\star}\end{array}$ \\
\hline \multicolumn{7}{|l|}{ Levy exempt drinks } \\
\hline Milk and milk based drinks & $-12.9(-21.3 \text { to }-4.5)^{\star}$ & $-7.9(-12.7 \text { to }-3.1)^{\star}$ & $5.9(-0.9$ to 12.7$)$ & $4.1(-0.7$ to 8.9$)$ & $-11.9(-23.1 \text { to }-0.8)^{\star}$ & $-7.4(-13.8 \text { to }-0.9)^{\star}$ \\
\hline No added sugar fruit juices & $-0.2(-6.8$ to 6.5$)$ & $-0.4(-14.3$ to 13.6$)$ & $-2.1(-7.7$ to 3.5$)$ & $-4.4(-16$ to 7.2$)$ & $-0.8(-10$ to 8.3$)$ & $-1.9(-21.6$ to 17.9$)$ \\
\hline Drinks sold as powders (g) & $-1.8(-5.8$ to 2.1$)$ & $-9.8(-29.2$ to 9.6$)$ & $0.6(-2.6$ to 3.8$)$ & $3.7(-17$ to 24.5$)$ & $-1.6(-6.7$ to 3.5$)$ & $-8.9(-35.1$ to 17.3$)$ \\
\hline Confectionery (g) & $-31.8(-62.7 \text { to }-0.9)^{*}$ & $-16.4(-30.1 \text { to }-2.8)^{\star}$ & $\begin{array}{l}12.2 \\
(-12.8 \text { to } 37.1)\end{array}$ & 7.7 (-9 to 24.4$)$ & $-28.6(-69.3$ to 12.1$)$ & $-14.4(-32.5$ to 3.7$)$ \\
\hline
\end{tabular}

The counterfactual for low tier drinks crossed $0 \mathrm{~mL}$ shortly before the end of the study period thus predicting negative purchases; therefore the non-counterfactual estimate at the end of the study period was compared with the final week during which the counterfactual was a positive number.

*Significant difference at $95 \%$ confidence interval level.

health gains from the SDIL. However, we did not study the SDIL's effect on purchases of other food groups or on overall diet.

In contrast with previous findings from Mexico and Barbados, ${ }^{6} 38$ we did not observe an increase in purchased bottled water associated with the SDIL. Indeed purchases of bottled water decreased significantly during the study period. Although we cannot rule out an effect of the SDIL on bottled water purchases, we cannot think of a plausible pathway through which it achieved reductions in purchased bottled water. Instead, this reduction might be due to coincident increases in concern about single use plastic that have been attributed, in the UK, to the broadcast of the nature documentary series Blue Planet 2 in October-December 2017. ${ }^{39}$ It is not clear if a similar "Blue Planet effect" has occurred in other countries. Unlike for many other soft drinks, a like-for-life substitution is available for bottled water in countries such as the UK-that is, filling reusable water bottles with tap water. Several UK retailers have reported substantial growth in sales of reusable water bottles since $2018 .^{40}$ Given that tap water is freely available, it is difficult to study changes in its consumption directly.

\section{Unanswered questions and future research}

Future work should seek to understand the longer term effects of the SDIL on purchasing and consumption of soft drinks as well as total diet, and health outcomes. Differential effects of the SDIL on all these outcomes across population groups (eg, by socioeconomic position and in households with versus without children) should also be explored to determine whether the SDIL contributes to narrowing inequalities in health. The changes in purchasing we report here could be used as an input to health impact modelling to estimate the effect of changes on population prevalence of obesity, diabetes, and other chronic conditions. It is likely that the reformulation that has occurred in response to the SDIL ${ }^{16}$ reflects substantial increases in the use of artificial sweeteners in the UK soft drinks market. Given public mistrust of artificial sweeteners, ${ }^{37}$ the effect of the SDIL on consumption of these should also be explored.

\section{Conclusion}

One year after implementation of the SDIL, purchased sugar in soft drinks decreased by around $30 \mathrm{~g}$ per household per week without a change in the volume of purchased soft drinks. This tiered tax aiming to stimulate industry to remove sugar from soft drinks might represent a benefit for public health (by reducing sugar purchased from soft drinks without substitution to confectionery and alcohol) without any commensurate harm to the soft drinks industry (by not affecting total volume of soft drinks purchased).

\section{AUTHOR AFFILIATIONS}

${ }^{1}$ Centre for Diet and Activity Research, MRC Epidemiology Unit, University of Cambridge School of Clinical Medicine, Institute of Metabolic Science, Cambridge CB2 OQQ, UK

${ }^{2}$ Faculty of Health, School of Kinesiology and Health Science, Toronto, Canada

${ }^{3}$ Centre on Population Approaches for Non-Communicable Disease Prevention, Nuffield Department of Population Health, University of Oxford, Oxford, UK

${ }^{4}$ Warwick Medical School, University of Warwick, Division of Health Sciences, Coventry, UK

${ }^{5}$ Population Health Innovation Lab, Department of Public Health, Environment and Society, London School of Hygiene and Tropical Medicine, London, UK

${ }^{6}$ National Institute of Health Research Oxford Biomedical Research Centre, Oxford University Hospitals NHS Foundation Trust, Headington, Oxford, UK

${ }^{7}$ Department of Social and Policy Sciences, University of Bath, Bath, UK

${ }^{8}$ College of Medicine and Health, University of Exeter, Exeter, UK Contributors: MW, SC, MR, RS, HR, JA, PS, OM, AB, and TLP conceived the study and defined the analytical strategy. DP, JA, OM, TLP, and SS performed statistical analyses and provided preliminary interpretation of findings. DP, JA, OM, and TLP drafted the manuscript. All authors critically interpreted the results, revised the manuscript, provided relevant intellectual input, and read and approved the final 
manuscript. DP and JA had primary responsibility for the final content. A will act as guarantor. The corresponding author attests that all listed authors meet authorship criteria and that no others meeting the criteria have been omitted.

Funding: DP, OM, MW, and JA are funded by the Centre for Diet and Activity Research (CEDAR), a UK Clinical Research Collaboration (UKCRC) Public Health Research Centre of Excellence Funding from the British Heart Foundation, Cancer Research UK, Economic and Social Research Council, Medical Research Council, National Institute for Health Research (NIHR), and Wellcome Trust, under the auspices of the UKCRC. This project was funded by the NIHR Public Health Research programme (grant Nos 16/49/01 and 16/130/01). The work was also supported by the Medical Research Council (grant Nos MC UU 12015/6 and MC UU 00006/7). The views expressed are those of the authors and not necessarily those of the National Health Service, the NIHR, or the Department of Health and Social Care, UK. The funders had no role in study design, data collection and analysis, decision to publish, or preparation of the manuscript. DP had full access to all the data in the study and had final responsibility for the decision to submit for publication.

Competing interests: All authors have completed the ICMIE uniform disclosure form at www.icmje.org/coi_disclosure.pdf (available on request from the corresponding author) and declare: MW is director of the National Institute for Health Research Public Health Research Funding programme, and $\mathrm{OM}$ is currently on secondment at the UK Department of Health and Social Care and previously worked with Public Health England; no support from any organisation for the submitted work other than that described above; no financial relationships with any organisations that might have an interest in the submitted work in the previous three years; and no other relationships or activities that could appear to have influenced the submitted work. Ethical approval: Not required for secondary data analysis of anonymised data.

Data sharing: The statistical code for the analyses are available from https://github.com/MRC-Epid/SDILEvaluation. Kantar Worldpanel data are not publicly available but can be purchased from Kantar Worldpanel (http://www.kantarworldpanel.com). The authors are not legally permitted to share the data used for this study but interested parties can contact Kantar WorldPanel representative Sean Cannon (Sean.Cannon@kantar.com) to inquire about accessing this proprietary data.

The lead author affirms that the manuscript is an honest, accurate, and transparent account of the study being reported; that no important aspects of the study have been omitted; and that any discrepancies from the study as planned (and, if relevant, registered) have been explained.

Dissemination to participants and related patient and public communities: This work was presented at the 2020 annual scientific meeting of the Society of Social Medicine. We will issue a press release on this work and engage with media outlets as relevant. We will summarise our findings in a Twitter thread. A lay summary of this paper will be prepared in advance of publication and shared on the Medical Research Council Epidemiology Unit and Centre for Diet and Activity Research websites. We will share this summary with our networks of public health practitioners and policymakers through our social media accounts and regular e-newsletter. A lay summary of the findings of the wider project of which this is part will be made available on the National Institute for Health Research website.

Provenance and peer review: Not commissioned; externally peer reviewed.

This is an Open Access article distributed in accordance with the terms of the Creative Commons Attribution (CC BY 4.0) license, which permits others to distribute, remix, adapt and build upon this work, for commercial use, provided the original work is properly cited. See: http://creativecommons.org/licenses/by/4.0/.

1 Moynihan PJ, Kelly SAM. Effect on caries of restricting sugars intake: systematic review to inform WHO guidelines. J Dent Res 2014;93:8 18. doi:10.1177/0022034513508954

2 Imamura F, O'Connor L, Ye Z, et al. Consumption of sugar sweetened beverages, artificially sweetened beverages, and fruit juice and incidence of type 2 diabetes: systematic review, meta-analysis, and estimation of population attributable fraction. BMJ 2015;351:h3576. doi:10.1136/bmj.h3576

3 Xi B, Huang Y, Reilly KH, et al. Sugar-sweetened beverages and risk of hypertension and CVD: a dose-response meta-analysis. $\mathrm{Br}$ Nutr 2015:113:709-17. doi:10.1017/S0007114514004383
4 World Health Organization. Tackling NCDs: "Best Buys" and Other Recommended Interventions for the Prevention and Control of Noncommunicable Diseases. WHO, 2017

5 Teng AM, Jones AC, Mizdrak A, Signal L, Genç M, Wilson N. Impact of sugar-sweetened beverage taxes on purchases and dietary intake: Systematic review and meta-analysis. Obes Rev 2019;20:1187-204 doi:10.1111/obr.12868

6 Alvarado M, Unwin N, Sharp SJ, et al. Assessing the impact of the Barbados sugar-sweetened beverage tax on beverage sales: an observational study. Int J Behav Nutr Phys Act 2019;16:13. doi:10.1186/s12966-019-0776-7

7 Roberto CA, Lawman HG, LeVasseur MT, et al. Association of a Beverage Tax on Sugar-Sweetened and Artificially Sweetened Beverages With Changes in Beverage Prices and Sales at Chain Retailers in a Large Urban Setting. JAMA 2019;321:1799-810. doi:10.1001/jama.2019.4249

8 Royo-Bordonada MA, Fernández-Escobar C, Simón L, SanzBarbero B, Padilla J. Impact of an excise tax on the consumption of sugar-sweetened beverages in young people living in poorer neighbourhoods of Catalonia, Spain: a difference in differences study. BMC Public Health 2019;19:1553. doi:10.1186/s12889-0197908-5

9 Cawley J, Frisvold D, Hill A, Jones D. The impact of the Philadelphia beverage tax on purchases and consumption by adults and children. J Health Econ 2019;67:102225. doi:10.1016/j. ihealeco.2019.102225

10 Lee MM, Falbe J, Schillinger D, Basu S, McCulloch CE, Madsen KA. Sugar-Sweetened Beverage Consumption 3 Years After the Berkeley, California, Sugar-Sweetened Beverage Tax. Am J Public Health 2019;109:637-9. doi:10.2105/AJPH.2019.304971

11 Mytton OT, Eyles H, Ogilvie D. Evaluating the Health Impacts of Food and Beverage Taxes. Curr Obes Rep 2014;3:432-9. doi:10.1007/ s13679-014-0123-x

12 Falbe J, Rojas N, Grummon AH, Madsen KA. Higher Retail Prices of Sugar-Sweetened Beverages 3 Months After Implementation of an Excise Tax in Berkeley, California. Am I Public Health 2015;105:2194-201. doi:10.2105/AJPH.2015.302881

13 Alvarado M, Kostova D, Suhrcke M, et al, Barbados SSB Tax Evaluation Group. Trends in beverage prices following the introduction of a tax on sugar-sweetened beverages in Barbados. Prev Med 2017;105S:S23-5. doi:10.1016/j.ypmed.2017.07.013

14 Cawley J, Willage B, Frisvold D. Pass-through of a tax on sugarsweetened beverages at the philadelphia international airport. JAMA 2018;319:305-6. doi:10.1001/jama.2017.16903

15 Stacey N, Mudara C, Ng SW, van Walbeek C, Hofman K, Edoka I. Sugarbased beverage taxes and beverage prices: Evidence from South Africa's Health Promotion Levy. Soc Sci Med 2019;238:112465. doi:10.1016/j.socscimed.2019.112465

16 Scarborough P, Adhikari V, Harrington RA, et al. Impact of the announcement and implementation of the UK Soft Drinks Industry Levy on sugar content, price, product size and number of available soft drinks in the UK, 2015-19: A controlled interrupted time series analysis. PLoS Med 2020;17:e1003025. doi:10.1371/journal. pmed.1003025

17 Penney T, Adams J, Briggs A, et al. Theorising how the UK Soft Drinks Industry Levy could impact population level diet and health: Development of a multi-sectoral systems map. International Society for Behavioural Nutrition and Physical Activity, 2017.

18 Quirmbach D, Cornelsen L, Jebb SA, Marteau T, Smith R. Effect of increasing the price of sugar-sweetened beverages on alcoholic beverage purchases: an economic analysis of sales data. J Epidemiol Community Health 2018;72:324-30. doi:10.1136/jech-2017209791

19 Smith RD, Cornelsen L, Quirmbach D, Jebb SA, Marteau TM. Are sweet snacks more sensitive to price increases than sugarsweetened beverages: analysis of British food purchase data. BMJ Open 2018;8:e019788. doi:10.1136/bmjopen-2017-019788

20 Scheelbeek PFD, Cornelsen L, Marteau TM, Jebb SA, Smith RD. Potential impact on prevalence of obesity in the UK of a $20 \%$ price increase in high sugar snacks: modelling study. BMJ 2019;366:14786. doi:10.1136/bmj.14786

21 HM Revenue \& Customs. Soft Drinks Industry Levy 2016. https:// www.gov.uk/government/publications/soft-drinks-industry-levy/softdrinks-industry-levy.

22 Gauke D. Budget 2016. HM Treasury, 2016

23 HM Revenue \& Customs. Check if your drink is liable for the Soft Drinks Industry Levy. Secondary Check if your drink is liable for the Soft Drinks Industry Levy 2018. https://www.gov.uk/guidance/checkif-your-drink-is-liable-for-the-soft-drinks-industry-levy.

24 Public Health England. Sugar reduction: Report on progress between 2015 and 2018. Public Health England, 2019.

25 Bandy LK, Scarborough P, Harrington RA, Rayner M, Jebb SA. Reductions in sugar sales from soft drinks in the UK from 2015 to 2018. BMC Med 2020;18:20. doi:10.1186/s12916-019-1477-4 
26 British Soft Drinks Association. 2018 Annual Report. British Soft Drinks Association, 2019.

27 Pell D, Penney TL, Mytton O, et al. Anticipatory changes in British household purchases of soft drinks associated with the announcement of the Soft Drinks Industry Levy: A controlled interrupted time series analysis. PLoS Med 2020;17:e1003269. doi:10.1371/journal.pmed.1003269

28 White M, Cummins S, Rayner M, et al. Evaluation of the health impacts of the UK Treasury Soft Drinks Industry Levy (SDIL). NIHR Public Health Research Programme, 2017.

29 Webber D, O'Neill J. Average household income, UK: financial year ending 2019; Estimates of median and mean disposable income for people in the UK for the financial year ending 2019. 2020. https://www.ons.gov.uk/peoplepopulationandcommunity/ personalandhouseholdfinances/incomeandwealth/bulletins/ householddisposableincomeandinequality/financialyearending2019

30 Lopez Bernal J, Cummins S, Gasparrini A. The use of controls in interrupted time series studies of public health interventions. Int Epidemiol 2018;47:2082-93. doi:10.1093/ije/dyy135

31 Zhang F, Wagner AK, Soumerai SB, Ross-Degnan D. Methods for estimating confidence intervals in interrupted time series analyses of health interventions. J Clin Epidemiol 2009;62:143-8. doi:10.1016/i.jclinepi.2008.08.007

32 Knipe E. Families and households in the UK: 2017; Trends in living arrangements including families (with and without dependent children), people living alone and people in shared accommodation, broken down by size and type of household. 2017. https://www.ons. gov.uk/peoplepopulationandcommunity/birthsdeathsandmarriages/ families/bulletins/familiesandhouseholds/2017

33 Smith K, Griffith R, O'Connell M. Measuring the quality of people's diets: a comparison of intake and purchase data. Econometrics and 10 of food and nutrition. Toulouse School of Economics, 2012.
34 Briggs ADM, Mytton OT, Kehlbacher A, et al. Health impact assessment of the UK soft drinks industry levy: a comparative risk assessment modelling study. Lancet Public Health 2016;2:e15-22. doi:10.1016/S2468-2667(16)30037-8

35 Law C, Cornelsen L, Adams J, et al. The impact of UK soft drinks industry levy on manufacturers' domestic turnover. Econ Hum Biol 2020;37:100866. doi:10.1016/j.ehb.2020.100866

36 Law C, Cornelsen L, Adams J, et al. An analysis of the stock market reaction to the announcements of the UK Soft Drinks Industry Levy. Econ Hum Biol 2020;38:100834. doi:10.1016/j. ehb.2019.100834

37 Pell D, Penney T, Hammond D, Vanderlee L, White M, Adams I. Support for, and perceived effectiveness of, the UK soft drinks industry levy among UK adults: cross-sectional analysis of the International Food Policy Study. BMJ Open 2019;9:e026698. doi:10.1136/bmjopen-2018-026698

38 Colchero MA, Popkin BM, Rivera JA, Ng SW. Beverage purchases from stores in Mexico under the excise tax on sugar sweetened beverages: observational study. BMJ 2016;352:h6704. doi:10.1136/bmj. h6704

39 Males J, Van Aelst P. Did the Blue Planet set the Agenda for Plastic Pollution? An Explorative Study on the Influence of a Documentary on the Public, Media and Political Agendas. Environmental Communication, 2020:1-15.

40 O'Mahony A. The rise and fall: bottled water category report 2020 Secondary The rise and fall: bottled water category report 2020 2020. https://www.thegrocer.co.uk/category-reports/the-rise-andfall-bottled-water-category-report-2020/603079.article

\section{Supplementary information: additional material}

